\title{
ISLAMISM IN MADURA From Religious Symbolism to Authoritarianism
}

\author{
Abd A'la \\ UIN Sunan Ampel Surabaya - Indonesia | abdalabs@yahoo.com \\ Mukhammad Zamzami \\ UIN Sunan Ampel Surabaya - Indonesia | zamzami81@yahoo.com \\ Nur Hidayat Wakhid Udin \\ UIN Sunan Ampel Surabaya - Indonesia | nhwahiduddin@gmail.com \\ Ahmad Fathan Aniq \\ McGill University - Canada | ahmad.aniq@mail.mcgill.ca
}

\begin{abstract}
The article scrutinizes the role and action of a number of Muslim organizations established by some prominent kiais in Pamekasan Madura, namely Badan Silaturrabmi Ulama Pesantren Madura (BASSRA/The Board of Madurese Pesantren Ulama), Aliansi Ulama Madura (AUMA/The Alliance of Madurese Ulama), and Forum Kiai Muda (FKM/The Forum of Young Kiais). These organizations, on the basis of their religious thoughts and movements, have been able to massively mobilize and organize their followers while at the same time create a multi-layered sectarianism. The sectarianism promulgated by these organizations seems to disrespectfully neglect interreligious and interethnic relations which rest within heterogeneous reality of the Madurese society. Consequently, the domination of the religious elites seems to "lock" the freedom of thought in religion. This article argues that Islamism in Pamekasan-as a variant of Islam in response to the global phenomena on religious fundamentalism-has uniquely focused on what so-called "nationalization of Islam". It implies that the Islamist groups in Pamekasan attempt to mobilize their followers, on behalf of Islam, in order to not only establish an Islamic state but also to renovate Indonesia.
\end{abstract}

Keywords: Islamism; the Madurese society; kiai.

\section{Introduction}

The study of Islamism is a study of conflict and tension. The underlying argument is that political, economic, and social interests are 
articulated in relation to religious claims; hence this may be called political religion. In fact, Islamists are struggling to "renew the world" or al-thawrah al-Islamiyah (Revolution of Islamic world)—adopting Sayyid Qutb's apt phrase. ${ }^{1}$ France calls Islamism movement as intégrisme, while others call it fundamentalism. All refer to the basic issue in Islamism's ideology, i.e. politicization of Islam to uphold a Sharia state. The ideology is embraced by a transnational movement consists of non-state actors. ${ }^{2}$

The development of Islamism in Indonesia found its momentum when the space of freedom of expression was widely opened in the 1998 post-Reform Era. At the end of Suharto's regime, Indonesia experienced a multi-sector crisis. Therefore, to solve the crisis, the Indonesian Islamists have craved the revival of the history and glory of Islam by promulgating the implementation of the Sharia as a solution to the crisis. Therefore, it has been proclaimed that Islamist movement is part of the politicization of Islam. The agenda is to construct religionized politics (tasyis al-Isläm) by making it an alternative political ideology.

The momentum of Islamism growth also developed in Pamekasan Madura. Pamekasan, a district in Madura Island, is known to be part of the excitement of the post-Reform Islamist groups in implementing Sharia through the establishment of local regulations. The Project of the Gerbang Salam (Gerakan Kebangkitan Masyarakat Islami/The Awakening Movement of Islamic Community $)^{3}$ in Pamekasan declared

\footnotetext{
${ }^{1}$ Revolutionizing the Islamic world as suggested by Sayyid Qutb, for he saw Muslims are entering into the age of "modern Jahiliya", i.e. modernity as "new barbarity". Quṭb's concept was then transmitted by Abu al-A'la al-Mawdudi into the Arab world. The idea of Quṭ can be further seen, among other, in the works of Muhammad Quṭb, Jähillìyat al-Qarn al-Ishrin (Cairo: Dār al-Shurūq, 1964).

2 Bassam Tibi, Islamism and Islam, trans. Alfathri Adlin (Bandung: Mizan, 2016), p. 48.

3 Although the history of Islamic shari'a legislation in Pamekasan was initially originated only from the political tactics of the former regent, Dwiatmo Hadianto (1999-2004), to gain the support of santri and kiai in the midst of political turbulent in the post-Reformation, but the next stage could be regarded as a political experiment of santri in establishing what so-called "bureaucratic of santri". This idea was first discoursed in 2001 with the release of Local Regulation Number 18 on the prohibition of alcoholic drink distribution. The discourse of Islamic Shari'a legislation in Pamekasan began to roll out among the elite of Islamic political parties and kiai. From this point, the idea of Islamic Shari'a legislation is pushed further by establishing the Institute for the Assessment and Application of Islamic Sharia (LP2SI) through the Decree of the Regent of Pamekasan Number 188/126 / 441.012/2002. See the
} 
in 2002, for an instance, is obviously linked to the current Sharia movement with special reference to Cianjur, a district in the West Java Province which is currently keen to withdraw society through the state. ${ }^{4}$

The passing of Sharia formalization in Pamekasan clearly sparked various Islamic thought in the city. Some important issues to note in this study comprise: firstly, the position of the 'ulama $\bar{a}$ ' of Nahdlatul Ulama (NU)_an organization with a dominant follower in Pamekasan-is not linear with the effects produced. Some other groups beyond NU, especially Sarekat Islam (SI) has been a party which is remarkably able to play a significant role in the region. The 'ulamā' of SI are able to organize socio-religious issues. Secondly, the figure of 'ulamà' as patron of the community will foster ideas of Islamism rather than nationalism. In general, community who become their followers will always obey their commands and advices; this includes providing them political support. Thirdly, the previously lessdominant group yet succeeded in packing the issue of Islamism as the sole best solution to moral crisis, and other crises indeed, will become increasingly popular in organizing socio-religious issues. The fourth is condition, which brings about the emergence of other group variants that will express their ideas in response to peoplehood, social, political, and religious problems. The establishment of Badan Silaturrahmi Ulama Pesantren Madura (BASSRA), Aliansi Ulama Madura (AUMA), and Forum Kiai Muda Madura (FKM) has clearly marked the growth of Islamism in Madura. These organizations possess legality issued by the Ministry of Justice and Human Rights, so they can freely guard humanitarian issues as the "vehicle" as for old organizations, like NU, are less alert in accommodating the current socio-religious issues.

Gerbang Salam review in Erie Hariyanto, "Gerbang Salam: Telaah atas Pelaksanaanya di Kabupaten Pamekasan", KARSA: Journal of Social and Islamic Culture, Vol. 17, No. 1 (April 2009).

4 In 2001, the Cianjur District Government issued four Islamic sharia-based regulations, are: the Decree Number 451/2712/ASSDA.I/2001 on the Obligation of Wearing Hijab in Cianjur; Circular Letter Regent Number 451/2719/ASSDA I/2001 on the Movement of the Apparatus of Berakblaqul Karimah and the Society of Marbamab; the Decree Number 36/2001 on the Establishment of Institute for Assessment and Development of Islam (LPPI); and Regent Circular Letter Number 551/2717/ASSDA/2001 concerning Public Services based on the Moral of Islam and the Islamic Society. 
Such organizations have actively sounded their ideas on several issues at the local level of Pamekasan as well as the national level. There have been a number of issues launched such as the issue of the so-called "true Sunni" vis-à-vis the "false Shī'a", ${ }^{5}$ establishment of Madura as a province, ${ }^{6}$ non-Muslims leaders, ${ }^{7}$ religious defamation, ${ }^{8}$ repudiation of misguided ideology, ${ }^{9}$ prohibition of LGBT (Lesbian, Gay, Bisexual, and Transgender), ${ }^{10}$ and rejection of standardization and certification of preachers. ${ }^{11}$ The most current issue they have echoed was religious defamation committed by Basuki Tjahaja Purnama (Ahok).

These organizations have consolidated themselves and shared the common voice in responding to the case. They also held a tabligh akbar (massive religious speech) on Thursday, April 13, 2017 at the Arek Lancor Monument in Pamekasan. Muhammad Rizieq Shihab, the prominent leader and figure of Front Pembela Islam (FPI) attended the event. The less-dominant mass organizations in Pamekasan such as Muhamadiyah, SI, Hidayatullah, Persatuan Islam (Persis) and al-Irsyad, and Hizbut Tahrir Indonesia (HTI) filled up the arena. They united themselves on the issue of Islamism and, seemed for a while, abandoned their ideological differences. Compared to the basic ideas of Islamism, ${ }^{12}$ these organizations have potential to produce even further ideas. Based on the aforementioned phenomenon, this article attempts to review the contributions and actions of several mass

\footnotetext{
5 "Sunni-Syiah: Politik Penyesatan vs Politik Kewargaan", http://liputanislam.com/opini. Accessed on 15 September 2017.

6 "Syarat Pembentukan Provinsi Baru Diuji", http://www.mahkamahkonstitusi.go.id/index. Accessed on 18 July 2017.

7 “Tunjuk Pengacara Aliansi Ulama Madura akan Laporkan Ahok ke Polda Jatim", http://portalmadura.com. Accessed on 15 June 2017.

8 "Ulama se-Madura Laporkan Ahok ke Polda" http://beritaotomatis.blogspot.co.id/2016/10/. Accessed on 12 June 2017.

9 "Antisipasi Masuknya Paham Wahabi dan Syiah, Auma Dideklarasikan", http://maduranewsmedia.com/terkini/. Accessed on 11 February 2017.

10 "Ulama Madura LGBT Ancam Keberlangsungan Peradaban Manusia", http://news.okezone.com/read/2016/02/19 /519/1316657/; http://m.metrotvnews.com/read/2016/02/22/487916/. Accessed on 12 June 2017.

11 http://www.suaranews.co/2017/02/ulama-madura-kami-menolak-tegas.html/. Accessed on 12 July 2017.

${ }_{12}$ Generally, there are six issues raised by the Islamist movement, as will be explained in the next part of this article. See, Tibi, Islamism, p. 7.
} 
organizations in Pamekasan in overseeing the current problems and how they promulgate the ideas of Islamism in the region.

This article examines Islamism in Pamekasan, Madura. It takes a different point of view from other studies related to Islam in Madura. There have been a bunch of previous studies trying to look at the relation of Islam and Madura such as the works of Huub de Jonge, ${ }^{13}$ Martin van Bruinessen, ${ }^{14}$ Kuntowijoyo, ${ }^{15}$ Iik Arifin Mansurnoor, ${ }^{16}$ Elly Touwen-Bouwsma, ${ }^{17}$ and Yanwar Pribadi. ${ }^{18}$ This article focuses on the activities of several Muslim organizations established by several religious elites in Pamekasan as mentioned above, namely the BASSRA, the AUMA, and the FKM, in which the creation of Islamic thought and movements is able to massively organize the mass and also to potentially form what so-called "layered sectarianism". The sectarianism hold by the Islamist movements in Pemekasan seems to deny the reality of diversity within inter and intra ethnic groups, as if

${ }^{13}$ Huub de Jonge, Madura dalam Empat Zaman: Pedagang, Perkembangan, Ekonomi, dan Islam (Jakarta: Gramedia, 1989).

14 Martin van Bruinessen, "Tarekat and Tarekat Teachers in Madurese Society," in Kees van Dijk, Huub de Jonge and Elly Touwen-Bouwsma (eds), Across Madura Strait: the Dynamics of an Insular Society (Leiden: KITLV Press, 1995).

${ }^{15}$ Kuntowijoyo, "Agama Islam dan Politik: Gerakan-gerakan Sarekat Islam Lokal di Madura 1913-1920", in Huub de Jonge (ed.), Agama, Kebudayaan, dan Ekonomi (Jakarta: Rajawali Press, 1989).

${ }^{16}$ Iik Arifin Mansurnoor, Islam in an Indonesian World: Ulama of Madura (Yogyakarta: Gadjah Mada University Press, 1990).

${ }^{17}$ Elly Touwen-Bouwsma, "The Ulama of Madura: Rise and Expansion of a Religious Administration," in Mart Bax et.al (eds), Faith and Polity on Religion and Politics (Amsterdam: VU University Press, 1992).

18 Yanwar Pribadi, "Kiai in Madura: Their Roles in Local Politics in Indonesia", American Journal of Islamic Social Sciences, Vol. 29, No. 3 (2012), 1-22; Yanwar Pribadi, "Religious Networks in Madura: Pesantren, Nahdlatul Ulama and Kiai as the Core of Santri Culture", Al-Jamiah: Journal of Islamic Studies, Vol. 51, No. 2 (2013), 1-32; Yanwar Pribadi, "Relasi Kiai, Masyarakat, dan Negara: Konfigurasi Politik Pemilu pada Masa Orde Baru di Madura", Maarif: Arus Pemikiran Islam dan Sosial, Vol. 8, No. 2 (2013), 183-201; Yanwar Pribadi, "Renegotiating Islam: The Kiai and People's Resistance against the Government in the 1993 Nipah Dam Incident in Sampang, Madura”, The 13th Annual International Conference on Islamic Studies (AICIS), 2013; Yanwar Pribadi, "Village Politics in Madura, Indonesia: Influential Community Figures in Search of Influence", The 14th Annual International Conference on Islamic Studies (AICIS), Balikpapan 2014; Yanwar Pribadi, "The Suramadu Bridge Affair: Un-bridging the State and the Kiai in New Order Madura", Studia Islamika, Vol. 22, No. 2 (2015). 
the dominant religious elites "lock" the space of freedom of thought in religion.

This article starts with an effort to describe three profiles of the aforementioned Muslim organizations developing in Pamekasan. This article then tries to analyze how these organizations, through the pesantren and the santri, build a strong base, and how religious symbols are used by the kiai in order to strengthen his charisma. The latter it attempts to analyze the authorization of religious ideas of kiai against other anti-mainstream thought or interpretation.

\section{A Snapshot of Profiles of Muslim Organizations in Madura}

As mentioned above, this article selects three muslim organizations in Pamekasan Madura as they seem to represent the emergence of Islamism movement in the region. These organizations also play pivotal role in the development of religious thought in Pamekasan. In addition, they also share similar genealogy for these organizations are, in fact, linked from one to another.

\section{Badan Silaturrahmi Ulama Pesantren Madura (BASSRA)}

The BASSRA was initially established to respond to the industrialization of Madura Island as a part of the Suramadu bridge construction with long trade-off of the plan. Responding to this sizzling issue, a number of 'ulamä' such as Abdullah Schal from Bangkalan, Tidjani Djauhari from Sumenep, Mohammad Rofi'ie Baidlowi from Pamekasan, and Dhofir Syah from Sampang accompanied with other 'ulamä', indeed, held a meeting at the Pesantren Al-Amien Prenduan, Sumenep on July 17, 1991. These religious elites decided to establish a forum of Madurese 'ulamá' named BASSRA. ${ }^{19}$ They expect the organization will be able to oversee and maintain industrialization in Madura without undermining the moral order of the Madurese people and their religiosity.

The BASSRA is an organization with no modern and wellorganized management system. It has been a mere association of several 'ulamä' from several pesantrens in Pamekasan, no less or more. This can be observed in its organizational leadership. Chairman (called Koordinator) of the BASSRA is held by the most senior 'ulama'. The

19 Umar Faruq, "BASSRA dan Rencana Industrialisasi di Madura: Kajian Historis Peran Politik Kiai 1991-1997” (Unpublihsed BA Thesis, UIN Sunan Kalijaga, Yogyakarta, 2009), p. 3. 
BASSRA is currently coordinated by KH. Moh. Rofi'ie Baidlowi (the Head Master of Pesantren al-Hamidy, Banyuanyar, Pamekasan). ${ }^{20}$ The appointment of the board has been also clearly nuanced by "tradisi pesantren" (the tradition of pesantren), in which the appointment of someone to occupy a certain position is considered sufficient with no special reference to any electoral efforts.

The BASSRA, in addition, has no clear membership. Its members consist of pesantren and individual who runs pesantren. It is, therefore, open to anyone. The BASSRA has no a definitive official address. BASSRA's address is normally attached to the same address of its coordinator. The BASSRA has only central coordinator and district coordinator. The coordinators of each district may consist of more than one person, which is also very informal. ${ }^{21}$

While the background of its establishment was more than responding to industrialization of Madura and the development of the Suramadu Bridge, it has been obvious that the issue was the trigger. Extending issue is one of the strategies commonly used by many founders of an institution to give broader meaning to its existence than simply respond to a short-lived issue. After the issue of the Suramadu Bridge and industrialization plan disappeared, the BASSRA has been also voiceless. The BASSRA is then left as a mere memory in minds of many. ${ }^{22}$

In addition to industrialization issue, there have been several strategic issues in Madura escorted by the BASSRA such as Sunnī versus Shī'a issues in Sampang ${ }^{23}$ including anti-Shi' ${ }^{-} a$, da $a^{\mathfrak{w}}$ wah of anti-

20 The stewardship of the BASSRA is as follows: The Central Coordinator is KH. Moh. Rofi'ie Baidlowi, the Secretary is Badrut Tamam, S.Si, the Coordinator of Bangkalan City is KH. Nuruddin A. Rahman SH., the Coordinator of Sampang City is KH. Dja'far Shodiq, the Coordinator of Pamekasan City is KH. Nailur Rahman, and the Coordinator of Sampang City is KH. Dr. Ahmad Fauzi Tidjani, MA.

21 Abdullah Sattar, "Badan Silaturrahmi Ulama Madura (BASSRA): Dakwah Multi Fungsi”, Jurnal Komunikasi Islam, Vol. 02, No. 01 (June 2012), pp. 64-65.

22 Ahmad Zainul Hamdi, "Pergeseran Islam Madura: Perjumpaan Islam Tradisional dan Islamisme di Bangkalan, Madura, Pasca-Reformasi" (Unpublished PhD Dissertation, UIN Sunan Ampel Surabaya, 2015), p. 183.

23 They held a deliberation of all kiai in Madura with the Majelis Ulama Indonesia and the Madura Communication Forum of Madurese which alluded to the MUI fatwa of East Java. The fatwa of Shiite apostasy is in accordance with the guidelines for the making of fatwas. See "Ulama Madura Minta Polisi Tegakkan Hukum" http://edukasi.kompas.com/read/ 2012/09/07/20183989/. Accessed on 16 July 2017. 
liberalism and Wahhabism, ${ }^{24}$ and morality degradation related to porn video of Ariel, Cut Tari, and Luna Maya. Within economic issue, the BASSRA supported the local government to carry on the exploration of seismic drilling conducted by the SPE Petro China Madura in the area. $^{25}$

In spite of its aforementioned actions, within the recent years, the BASSRA's contribution in maintaining socio-religious issues in Madura has been poorly heard. Its voice seems to be defeated by its splinter organizations, namely the AUMA and the FKM. Some sources point out that the BASSRA's contribution has gradually decreased as its structure replaced. The replacement of the latest BASSRA's board composition puts some apolitical 'ulamà'. Its movements, which have been previously dominated by political and pragmatic 'ulama', are replaced by regimes that attempt to bring the BASSRA into 'ulamä' as the protectors for all people. Lora Muhammad Sholahuddin (wellknown as Gus Mamak) son of KH. Warits Ilyas (RIP), one of BASSRA's board members, explains that:

"The BASSRA's position in the last years has been very wise. Perhaps, it is also not contextual to me as it does rarely act and respond to socio-religious issues. Perhaps, too, the 'ulamā' composition in the stewardship structure of the BASSRA is dominated by the senior people. The BASSRA's position is that of a government partner yet in a critical perspective on its policies". ${ }^{26}$

Explaining the BASSRA's actions in recent years, Gus Mamak tends to see a symptom of 'ulama' conservatism in the organization. He implicitly adds that the senior 'ulamä' do, to some extent, not wisely put and use their position as the guardians of community. To him, the BASSRA has been now looks more like the AUMA in terms of its line

\footnotetext{
${ }^{24}$ It has been explained by the General Secretary of the BASSRA, KH. Drs. Nuruddin Abdurrahman, SH, stating that: "The BASSRA does consistently maintain 'aqidab of the society, enhances the solidarity among pesantren, and highlights the differences. This is in line with the BASSRA's vision, bringing together the kiai in Madura in order not to be divided only because of their methodological difference and political preference." See, "BASSRA Bentengi Aswaja Madura dari Wahabi Syiah dan Aliran Sesat", http://www.nugarislurus.com/2016/01/. Accessed on 24 June 2017.

25 Sattar, "Badan Silaturrahmi Ulama Madura (BASSRA)", p. 230.

${ }^{26}$ Muhammad Sholahuddin son of KH. Warits Ilyas, Interview, Pamekasan, 22 June 2017
} 
of thought. ${ }^{27}$ It should be noted, however, while the BASSRA's role decreases, some 'ulamà' still actively expresses their aspirations, especially in responding to Islamic issues.

\section{Aliansi Ulama Madura (AUMA)}

The AUMA was declared on Saturday, October 31, 2015 at the Pondok Pesantren Nurul Kholil, Bangkalan Madura, led by KH. Zubair Muntashor. The AUMA's central management was actually formed on July 21, 2015 in the Pesantren Darul Ulum Banyuanyar Pamekasan Madura with the agreement of the AUMA's management structure. The mission carried out by this organization is to protect the Muslim society, especially in Madura, from such harmful ideology of as Shī'a, Wahhabism, liberalism, and religious blasphemy (popularly known as SIBILIP). ${ }^{28}$ The AUMA's official headquarter is located in Proppo, Lanteng, Pamekasan, Madura.

Regarding the importance of protecting the Muslim society from misguided and erroneous ideologies, the chairman of the AUMA, KH. Ali Karrar, stressed that:

"The formation of the AUMA is a response to the existence of a number of misleading organizations, which propagate teachings that violate Islamic religious principles. Several ideologies, which contradict to Pancasila's philosophical values and Islam, have been embraced by many people, for an example, Shīah that clearly deviates from Islam". ${ }^{29}$

The General Secretary of the AUMA, KH. Fadholi M. Ruham, states that: "What we actually intend for the declaration of the AUMA is to maintain the purity of Islamic faith, so that Madura and Indonesia in general will be free of movements tarnishing their religion, particularly that of Shī'ah and liberalism". 30

\footnotetext{
27 Ibid.

${ }^{28}$ KH Ali Karrar Shinhaji, Interview, Pamekasan, 22 June 2017.

${ }^{29}$ Ibid.

30 "Ulama Madura Deklarasi Tolak Paham Sesat", http://www.republika.co.id/berita/nasional/daerah/15/11/01/ Accessed on 12 July 2017. This was also confirmed by KH. Fudholi Moh. Ruham's son, Lora Imadul Haq Fudholi, who asserted that the kiai in Madura need to voice their aspirations on socio-religious issues, because the kiai is seen as a moral force for Muslims in Pamekasan. The Muslim community in Pamekasan is more respectful to the kiai than the government apparatus. Imadul Haq Fudholi, Interview, Pamekasan, 22 February 2017.
} 
Fadholi argued that such ideologies are considered dangerous and can potentially harm unity of the nation. He exemplifies the current conditions of Syria and Yemen which are now ravaged by heretical sects. He further expects the same condition will never occur in Madura. Madura, in his opinion, is still now safe from disruptive religious teachings which violate the doctrines of Abl al-Sunnah wa alJamáa ${ }^{-} a h$ held by the vast majority of the Muslim society in Madura.

Based on our observation, some 'ulama' who have decided to leave the BASSRA are those who are unable to employ the organization to escort the latest issues in Madura. Recent developments suggest that as an organization, which guards Madura, the growth of the BASSRA tends to be gradually apolitical. This has subsequently led some of its members to establish a new "vehicle" to accommodate their aspirations. They have subsequently founded the AUMA.

All four districts in Madura have their representatives in the AUMA's central board. ${ }^{31}$ Each district has also its regional coordinator. The District of Pamekasan is led by KH. Nawawi Thoha and KH. Abd. Aziz Syahid. ${ }^{32}$ They have actively voiced out their opinions on such number of previously mentioned issues, at both local and national level, as the issue of Sunnī vis- ̀̀-vis Shīa a, ${ }^{33}$ establishment of Madura as a province, etc.

Compared to other districts in Madura, Pamekasan has heterogeneous religious groups and organizations. According to the LP2SI chairman, there are, at least, six existing religious organizations in Pamekasan, i.e. NU, Muhammadiyah, SI, Hidayatullah, Persatuan Islam (Persis), and al-Irsyad. Of the six mass organizations, the two

\footnotetext{
31 The structure of the board of the AUMA for the period of 2016-2020 is: The Founders are KH. Muhammad Syamsul Arifin of Pamekasan, KH. Abd. Bastih Faqih of Pamekasan, KH. Taufiqurrahman, FM of Sumenep, KH. Fauzi Rasul of Sumenep, KH. Mahrus Abd. Malik of Sampang, KH. Muhaimin Abd. Bari of Sampang, KH. Muhammad Faishol Anwar of Bangkalan, and KH. Zubair Muntashor of Bangkalan. The General Chairman is KH. Ali Karrar Shinhaji of Pamekasan. The General Secretary is KH. Drs. Fahdoli Moh. Ruham, M.Si of Pamekasan.

32 The AUMA Management Structure of Regional Coordinator of Pamekasan for 2016-2020 Period is: The Founders are KH. Muhammad Syamsul Arifin, KH. Jazuli Jauhari, KH. Abd. Ghafur Syafiuddin, KH. Hasibin, and KH. Mundzir Cholil. The Chairman is KH. Nawawi Thoha. The Vice Chairman is KH. Rosyad Imam, and the Secretary is KH. Abd. Aziz Syahid.

33 "Sunni-Syiah: Politik Penyesatan vs Politik Kewargaan", http://liputanislam.com/opini/. Accessed on 15 September 2017.
} 
dominant organizations in the region have been NU and SI. ${ }^{34}$ The composition of the AUMA's membership has also varied. Being the most dominant organization does not necessarily make NU overrule the AUMA's membership. There have been some 'ulama' affiliated to SI who hold strategic position in the organization. The AUMA's general chairman, for an instance, is now held by KH. Ali Karrar Shinhaji of SI, while its general secretary is held by KH. Fudholi Moh. Ruham of NU. It indicates that the distribution of power within the AUMA in Pamekasan has been relatively balanced. There has been no such a dominant membership in the AUMA.

The pattern of interaction among 'ulama' in Pamekasan, as the capital city of the Madura Island, has been certainly different from that of in the Western Madura areas, namely Bangkalan and Sampang. ${ }^{35}$ While 'ulam $\bar{a}$ ' in Bangkalan are still tied up in a vast network of kinship with one of the most charismatic figure of the Javanese and Madurese 'ulamà', i.e. Syaikhona Kholil, the social relationships among 'ulamä' of Pamekasan are relatively not bound by such an extensive network of kinship. They are not even hierarchically connected. Each "autonomous" "alim primarily interact with his followers and with such other social institutions as bureaucrats and legislatures. Within social structure, 'ulamā' have dominant social relations with their people. The same is true with local political structure where 'ulama' in the Eastern Madura, primarily Pamekasan, utilize it as one of their socio-political forces.

\section{Forum Kiai Muda (FKM)}

The FKM has initially appeared from the AUMA. While AUMA's membership is mostly dominated by senior 'ulamä' (many of them are kiai who lead pesantren), FKM is an organization whose membership is dominated by lora or gus or bhindhäräh. These terms usually refer to the mention of sons of kiai. This is a sort of call to pay a tribute to the sons of kiai. ${ }^{36}$ Zamakhsyari Dhofier describes lora as a young man who

\footnotetext{
${ }^{34}$ Mansurnoor, Islam in an Indonesian World, p. 120.

35 Mutmainnah, Jembatan Suramadu: Respon Ulama terbadap Industrialisasi (Yogyakarta: LKPSM, 1998).

${ }^{36}$ For the mention of kiai's son/kiai's family, each region has its own characteristics. The mention of gus is identical to the typical call in Java, while lora is a typical call in Madura. Bhindharab is a typical mention on kiai Pendalungan/in Eastern and Southern part of East Java. See, Abdul Chalik, "Elite Lokal Berbasis Pesantren dalam Kontestasi Pemilihan Kepala Daerah di Jawa Timur”, KARSA: Jurnal Sosial dan Budaya Keislaman,
} 
can pass on the advantages inherent in a kiai in both religious knowledge and supernatural power. ${ }^{37}$

The FKM was founded on August 9, 2015. In the formulation of its power of attorney, the membership of this organization consists of lora and/or preachers aged between $20-40$ years. ${ }^{38}$ The FKM is now headquartered in Pamekasan and chaired by Lora Umar Hamdan Karrar son of KH. Ali Karrar Shinhaji accompanied by his secretary Lora Imadul Haq Fadholi son of KH. Fadholi Moh. Ruham. This composition is clearly identical to that of the AUMA's chairman and secretary.

The line of thought between these two organizations is genealogically similar. While the AUMA accommodates the very ideological thoughts of old 'ulama', the FKM becomes a battle ground of the youngsters to practically express their ideas. Therefore, the role of the FKM is undoubtedly pivotal. This is so because the FKM appears "to translate" the ideas of its predecessor, i.e. AUMA. Many socio-religious issues echoed by the FKM are mostly identical to the issues escorted by the AUMA. Declaring itself as ideologically founded on the Abl al-Sunnab wa al-Jamäab (ASWAJA), the FKM rely its teachings upon the sources of Islamic doctrines, namely al-Qur'ān, alSunnah, al-Ijmā', and al-Qiyās. ${ }^{39}$ In addition, the members of the FKM have also routinely held da'wab to several areas. They have presented a number of resource persons such as KH. Lutfi Bashori of Malang, KH. Idrus Romli of Jember, and KH. M. Najih Maimun of Rembang in their da'wah. The last mentioned name had even conveyed the ASWAJA ideology on August 3, 2016 in Pamekasan. In their speech, the three speakers remind the Muslim community to fortify Islam according to the ideology and method of the ASWAJA.40

Vol. 23 No. 2 (December 2015), p. 371. Compare also with Nurcholish Madjid, Bilikbilik Pesantren: Sebuah Potret Perjalanan (Jakarta: Paramadina, 1997), p. 24.

37 Zamakhsari Dhofier, Tradisi Pesantren: Studi tentang Pandangan Hidup Kyai Jakarta: LP3ES, 1982), p. 32.

38 The Articles of The Forum of Kiai Muda Madura, published by the FKM.

${ }^{39}$ Imadul Haq Fadholi, Interview, Pamekasan, 21 February 2017. See also, AD-ART (the Statue) of the FKM.

${ }^{40} \mathrm{KH}$. Luthfi Bashori presented the theme of "Communist Dangers" with the phenomenon of Chinese power importers currently being promoted by the government under the Jokowi-Jusuf Kalla regime. Meanwhile, KH. Muhammad Najih Maimoen as the second speaker in his presentation also expressed his assertiveness that he remains istiqamah refusing the Aliran Nusantara (Anus) which is proven today 
The FKM has currently contributed to establish cooperation with several mass organizations such as Gerakan Umat Islam Pamekasan (GIUP) and Front Pembela Islam (FPI). Along with the latest mentioned organizations, the FKM held tabligh akbar (mass religious speech) on Thursday, April 13, 2017 at Arek Lancor Monument in Pamekasan. The event was attended by Muhammad Rizieq Shihab, the most prominent figure of the FPI. Other mass organizations such as Muhamadiyah, SI, Hidayatullah, Persis, al-Irsyad, and HTI also participated in the event. Daeng Ali Taufik, the chairman of Pengurus Daerah Muhammadiyah (PDM/The Muhammadiyah Regional Board) of Pamekasan attended the event and actively engaged in it. To him, religious blasphemy committed by Basuki Tjahaja Purnama has united Muslims from cross-ideology in Pamekasan. ${ }^{41} \mathrm{KH}$. Lailurrohman, the Chairman of the Harkat Pimpinan Pondok Pesantren se-Madura (HP3M), also holds similar argument stating that "It is time for Muslims to unite against any religious blasphemy". ${ }^{42}$

\section{Building Religiosity in Madura}

According to data launched by moslemwiki.com, Pamekasan has 278 pesantrens. ${ }^{43}$ Socially, the condition has significant implications for the design of ideology, education system, and culture. From ideological aspect, for an example, the existence of many pesantrens has influenced public religiosity in terms of its belief. This is so because one of the main purposes of pesantren is to preserve Islam within the society. While pesantren is frequently seen as an institution embedded with a number of objectives, all are set to achieve the main goal, i.e. the development of Islam. The population of Pamekasan has statistically

under the leadership of Prof. Dr. Said Agil Siradj that supports non-Muslim leader, Hary Tanoesoedibjo. While KH. Muhammad Idrus Ramli (an expert council of Aswaja NU Center of East Java) explains and exposes "Reject Wahabi and Shia" as a cult and the serpent in the bosom. Besides, liberal and communist sects along with their values, to these three kiais, must also be eradicated from our ideology of Ahl al-Sunnah Wa alJama'ah. See http:/ /www.nugarislurus.com /2016/08/ live-seminar-bersama-3-ulamasinga-aswaja-garis-lurus.html

${ }^{41}$ Daeng Ali Taufik, Interview, Pamekasan, 23 February 2017.

${ }^{42}$ KH. Lailurrahman, Interview, Pamekasan, 22 February 2017.

43 http://moslemwiki.com/Pesantren_di_Kota_Pamekasan/. Accessed 12 on July 2017. 
reached 726.908 people. ${ }^{44}$ Of this number, only $1 \%$ embraces other religions than Islam. It is therefore not surprising that Muslims in Pamekasan occupy almost all public offices.

As one of the districts in Madura, Pamekasan has been a part of the excitement of the post-reform Islamist groups in implementing Islamic law through the establishment of local regulations. The Project of Gerbang Salam declared in 2002 has been an obviously clear example of the correlation with the community's Sharia movement throughout the state. The presence of several Sharia bylaws in Pamekasan has always been linked to many factors, including historical past of the region that supported the establishment of an Islamic state and the presence of some community leaders who have an emotional bond with parties that support the establishment of an Islamic state such as Masyumi, PSII, and Persis. Local political constellation of fighting for supporters becomes another reason that led to the emergence of the Sharia regulation. Moreover, the existence and the nature of proponents involved in proposing and endeavoring for the emergence of the Perda Syariah in Pamekasan, or called as "internal reasons", are also indubitably important factors in this regard.

The 'ulamä' existence becomes an important factor in supplying the policy and Islamic social thought in Pamekasan. Respect for 'ulamä' takes place throughout the region, yet the respect for the 'ulam $\bar{a}$ ' in Pamekasan is stronger. Some of the reasons, which give legitimacy toward 'ulamä's role in Pamekasan or Madura in general are:

First, 'Ulama' in Pamekasan have extensive kinship networks, through inter-family marriage, students- 'ulamà' relationships, as well as similarities network organization. ${ }^{45}$ The strengthening of kinship

44 https://pamekasankab.bps.go.id/linkTabelStatis/view/id/191/. Accessed on 12 July 2017.

45 Inajati Adrisijanti et al., Ensiklopedi Pamekasan: Alam, Masyarakat dan Budaya (Pamekasan: Pemkab Pamekasan and Fakultas Ilmu Budaya Universitas Gadjah Mada, 2010), pp. 270-271. Some kiais in Pamekasan who run pesantren with large number of santri have kinship relationship among them. For example, the kinship of some kiai in Pamekasan based on genealogy can be seen in the offspring of Kiai Ahmad. There have been, at least, nine pesantren in Pamekasan led by the descendants of Kiai Ahmad, namely Pesantren Banyuanyar, Pesantren Miftahul Ulum Panyeppen, Pesantren Mambaul Ulum Bata-Bata, Pesantren Mambaul Ulum Bettet, Pesantren Miftahul Qulub Galis, Pesantren Panempan, Pesantren Sumber Bungur Pakong, Pesantren Ummul Qura Blumbungan, and Pesantren Sumber Batu Blumbungan. See, among other, Muhammad Kosim, et.al, Sejarah Pertumbuban dan Perkembangan Pondok Pesantren di Kabupaten Pamekasan (Pamekasan: STAIN Pamekasan, 2001), p. 15. 
networks among 'Ulamä' such as Pamekasan shows that 'ulamä' have significant followers. This implies that those 'ulamä' are worthy to be respected and obeyed as they have great power, including for mass mobilization.

Second, charisma of Kiai Kholil of Bangkalan has been another factor that encourages obedience and adherence of the Madurese community in general, including Pamekasan, upon 'ulama'.' The role of Kiai Kholil of Bangkalan as a teacher to many great scholars in Madura and Java has amazedly put that 'ulama' have been figures to whom obedience should be paid for. In the late nineteenth and early twentieth centuries, Kiai Kholil was a great scholar who became a teacher to most of the prominent 'ulamà' in Java such as Hasyim Asy'ari of Tebuireng Jombang, Wahab Hasbullah of Tambakberas Jombang, and a number of the Madurese 'ulamä'. Wahab Hasbullah had even been a student of Kiai Kholil for three years. ${ }^{46}$

Third, in Pamekasan, 'ulamä' belongs to oreng dhalem class, which historically possess a high social status for they have a lineage of the royal family. Pesantren Banyuanyar, for an instance, has a kinship with Sultan Pakubuwono II of Surakarta. One of Pakubuwono II's descendants, Abdullah, once married a woman from Larangan, Badung, Pamekasan. From this marriage the couple was blessed with several children, one of them was Kiai Agung or known as Bujuk Agung. One of the grandchildren of Bujuk Agung, Isbat, was the founder of the Pesantren Banyuanyar. ${ }^{47}$

Some of the great 'ulamä' in Pamekasan were (and are) also descendants of Adikoro, the King of Pamekasan Kingdom. They spread out in Sumberanyar, Banyuanyar and Batuampar, Pamekasan. ${ }^{48}$ It is therefore some of the great kiai in Pamekasan are called as "Raden" such as KHR. Abdul Hamid, KHR. Abdul Madjid, and KHR. Muhammad Rofi'i Baidawi. ${ }^{49}$ In addition to the genealogical factors, the 'ulamà' also received the title of nobility as an award from the

\footnotetext{
46 Ibid., p. 92.

${ }^{47}$ Mansurnoor, Islam in an Indonesian World, p. 229.

48 Zainalfattah, Sedjarah tjaranja pemerintahan di daerah-daerah di kepulauan Madura dengan bubungannja (n.p.: Paragon Press, 1952), p. 107.

49 Adrisijanti, Ensiklopedi Pamekasan, p. 275.
} 
Dutch colonialist, especially for those who are considered able to cooperate with them. ${ }^{50}$

Compared to other districts in Madura, Pamekasan has heterogeneous religious organizations as mentioned above. Of the existing organizations, NU and SI have been massively embraced by the vast majority of Muslims and become the dominant organizations in the area. ${ }^{51}$ In addition, there are also new organizations which share the same membership with the aforementioned mass organizations. Among these organizations are BASSRA, AUMA, FKM, HP3M, and Gerakan Santri dan Pemuda Rahmatan Lilalamin (Gasper). They vigorously color the dynamics of Islamic thought and movement in Pamekasan.

Historically, the advent of SI into Madura was before the 1920s prior to the arrival of the newly established NU in Surabaya in 1926. In Pamekasan, SI branch was inaugurated on February 9, 1914, a year after this organization entered Sampang in April 1913.52 Nevertheless, NU that came later in Madura, also received sympathy from the community and gained many followers. The success of NU gained great support, one of which was caused by the failure of SI to fulfill the mandate of its party, due to internal conflict at the level of central leadership which had implications to almost all its branches, including Pamekasan. The magnitude of NU in Pamekasan is also influenced by the process of its emergence involving figures in Pamekasan, such as As'ad Syamsul Arifin. Though in the aftermath of its establishment in Pamekasan As'ad had moved to Situbondo, the existence of NU he had pioneered still firmly attached to the hearts and emotions of the people of Pamekasan. ${ }^{53}$

In addition, the advent of $\mathrm{NU}$ in Madura was at the time a response towards the emergence of Muhammadiyah that insisted to purify the teachings of Islam. Muhammadiyah, which has arrived to Madura since the 1920s, opposed the practice of pre-Islamic traditions within the Muslim community. ${ }^{54}$ It has subsequently led to resistance

50 A. Latief Wiyata, Carok: Konflik Kekerasan dan Harga Diri Orang Madura (Yogyakarta: LKiS, 2006), p. 33.

51 Mansurnoor, Islam in an Indonesian World, p. 120.

52 Kutwa, et.al, Pamekasan dalam Sejarah (Pamekasan: Pemerintah Daerah Pamekasan, 2004), p. 123.

53 Ibid., p. 127.

54 de Jonge, Madura dalam Empat Zaman, p. 247. 
from the local community. NU, on the contrary, has taken different standpoint and attitude for it is able accommodated the local traditions and also able to negotiate with the existing traditions maintained by the community, while at the same time also attempted to nurture Islam and its teachings among the community. According to Huub de Jonge, Muhammadiyah has tried to realize certain wisdom, while NU was more fighting for a certain mentality. ${ }^{55}$

Significantly high number of SI's membership in Pamekasan over NU has strongly correlated to the domination and influence it fight for. Historically, SI - that emerged and developed earlier in Madurawas able to play a significant role. In addition, SI in Pamekasan has managed to attract the sympathy of the prominent pesantren leaders and 'ulama'. It has implications for the influence that arises in society even nowadays. Moreover, the majority of mass organizations other than NU and SI in Pamekasan hold almost similar ideology to SI. Therefore, moderate attitudes which aims at preserving religious traditions held by NU are in rivalry against the puritanical ideology promulgated by SI. 56

SI has been a political movement that extensively struggles to unite people. The society suffered severely due to Dutch's oppression. Therefore, SI guided and rested on the unity of the absolute nation. Without unity the struggle to obtain the rewards would have never been conceivable. ${ }^{57}$

Puritanical model of thought practiced by the religious elite in Pamekasan clearly manifests itself in the exclusive attitude of religion and state relations. The 'ulama' fear of that political modernization in the post-Reformation, especially in Pamekasan, will to a lesser extent lead to political secularization. ${ }^{58}$ Their fear is, somehow, groundless. This is so because in a country with Pancasila as its main ideology, the process of political modernization will not lead to a secular state. The relationship between religion and state in Indonesia is the relationship

\footnotetext{
55 Ibid., p. 248.

${ }^{56}$ Kutwa, Pamekasan dalam Sejarah, p. 124.

${ }^{57}$ M. Abdul Gani, Cita Dasar dan Pola Perjuangan Syarikat Islam (Jakarta: Bulan Bintang, 1984), pp. 80-81.

58 The anxiety of the kiai who are members of the BASSRA community in responding to the industrialization through the construction of the Surabaya-Madura bridge. The kiai are afraid of Madura will subsequently become a very secular area. See, Mutmainnah, Jembatan Suramadu.
} 
of intersection; not fully integrated and not separated completely. It needs to be bluntly admitted that in the aftermath 1998 Reformation, freedom of expression in certain cases has led to disputes and conflicts that nearly could disrupt social harmony and national integration. It is in this context, therefore, the Islamic elites in Pamekasan need to contribute positively as integrative agents who highly appreciate and promote plurality among the society and preventing themselves from being supporters to exclusivism.

\section{Islamism in Pamekasan: Between Symbolism and Authoritarianism}

Islamism can also be termed as political Islam. Muhammad Sa ${ }^{a} \bar{i} d$ al-Ashmāwī —an Egyptian jurist and state administration expert-calls them the last term. He named the two as al-Islam al-Siyasi or political Islam. Some scholars then named this group as Islamism. Mehdi Mozaffari defines Islamism as a religious ideology with a holistic interpretation of Islam with the aim of conquering the world by all means. ${ }^{59}$ At the very least, this definition contains four important interrelated elements, are: the religious ideology, the holistic interpretation of Islam, the conquest of the world, and the use of all means to seek the ultimate goal.

Hannah Arendt, for an example, calls Islamism the totality of Islamic ideology, i.e. totalitarianism. In this sense, Islamism does not agree with an inclusive and liberal Islam, because-as a religionIslam has comprised all worldly and heavenly matters. ${ }^{60}$ As an ism, totalitarianism consists of such various meanings as ideology, movement, and political array. ${ }^{61}$ In line with Bassam Tibi who studies Islamism using the aforementioned approach developed by Arendt, we intend to do so in examining Islamism promulgated by the young kiais in Pamekasan Madura.

Olivier Roy—a French Islamologist-has extensively used the terms of political Islam and Islamic fundamentalist to refer to these ideological Muslim groups, but he later prefers to use Islamism more. Within Roy's terminology, there has been a difference between

59 Mehdi Mozaffari, "What is Islamism? History and Definition of a Concept", Totalitarian Movements and Political Religions, Vol. 8, No. 1 (March 2007), pp. 17-33.

${ }^{60}$ Hannah Arendt, The Origins of Totalitarianism (New York: Harcourt Inc., 1951). Compare to Hannah Arendt, "The Totalitarianism of Jihadist Islamism", Totalitarian Movement and Political Religion, Vol. 8, No. 1 (March 2007), pp. 25-54.

${ }^{61}$ Arendt, The Origins of Totalitarianism. 
political Islam and Islamism. While the first refers to a failed project of the modern Muslims, Islamism is-for him-then "a new phenomenon" of Muslims' activism in contemporary century. ${ }^{62}$

Generally, there are six issues raised by the Islamist movement, are: the interpretation of Islam as al-nizàm Islami (Islamic state order); the perception of the Jews as the main enemy who conspire with their allies to fight against Muslims, for they are believed to establish "the Jewish world order"; democratization and the position of institutional Islamism within a democratic state; the evolution of jihad from its classic meaning into terroristic jihadism; remaking of Sharia; and the issues of purity and authenticity, which determine the Islamist view on secularization and de-secularization.

Within the context of Islamic culture in Pamekasan, santri have high obedience to kiai or 'ulamă'. In addition, there has been also a sort of legacy of understanding maintaining that in order to have beneficial knowledge, a santri must also respect the sons and daughters of his/her teacher. According to Zamakhsyari Dhofier, the sons and daughters of kiai are imaged as being capable to inherit both science and supernatural powers from their parents. ${ }^{63}$ To proof their respect, observance, and obedience towards their kiai and teachers, for an example, the students need to visit pesantren even when the teachers have passed away already. ${ }^{64}$

In Pamekasan, like in other areas of Madura, the 'ulamā' enjoy the highest stratum in religious sphere beyond two other strata, namely bindhara and santri. Bindhara are people who graduated from pesantren and they also possess sufficient religious knowledge, while santri are people who are studying at pesantren. Of these stratifications, it can be understood that 'ulamā' or kiai possess mass-base which consists of bindhara and santri. 65

In the context of submission to the 'ulamà', the emergence of the Sharia by-law in Pamekasan has a close relationship. Historically, the regulations have been natively initiated from 'ulama $a$ 's strong desire to make regulations derived from Islamic values. Such intention has been

62 Olivier Roy, Globalised Islam: The Search for a New Ummah (London: Hurst and Company, 2002).

${ }^{63}$ Dhofier, Tradisi Pesantren, p. 32.

${ }^{64}$ Ibid., p. 82.

65 Mohammad Muchlis Sholichin, "Perilaku Politik Kiai di Pamekasan", KARSA: Jurnal Sosial dan Budaya Keislaman, Vol. XV (2009), p. 49. 
voiced by the political party through its representatives in the legislature and finally passed it onto the executive. At the same time the legislative and executive elites in Pamekasan are uniquely also santri who hold high obedience to the 'ulama $\bar{a}$; a typical tradition of relationships among santri-'ulam $\bar{a}$ ' within the culture of pesantren.

Some advantages enjoyed by the 'ulamā' include networking, charisma, and miracles that commonly become reference to whom the people refer to. Thus, 'ulamä are able to easily optimize the mobilization of their followers. Viewed from James Scot's theory of patron-client, ${ }^{66}$ the 'ulamä' are able to become a patron and uswab to the society ${ }^{67}$ through their charisma. Meanwhile, Muslim society or santri, as the clients, fully obey advices and instructions of the 'ulama', including giving support to 'ulamä's political choice. The symbiotic relationship between patron-client becomes more intensive when the two need each other. In this position, the 'ulamā' manifest their existence by the recognition of santri to the depth of his spiritual knowledge. Santri become objects that always hope for blessing due to their submission to the 'ulamä'. Santri always see 'ulamä' as the successors and inheritors to prophets.

'Ulama's ability to rally masses who obey them will place the 'ulamä' as a patron for political elites who need massive support. Meanwhile, political elites become a client to 'ulama $\vec{a}$ who will provide them facilities, i.e. pesantren and santri. Similarly, 'ulamà' who successfully support political elites will confirm their existence and power before the eyes of the political elites. Hence, they will subsequently possess stronger bargaining power. ${ }^{68}$

This relationship is similar to relationship pattern between ego (alana) and the other (al-äkhar ${ }^{69}$ where 'ulamä' play the ego and santri as the

${ }^{66}$ James C. Scott, "Patron-client Politics and Political Change in Southeast Asia", American Political Science Review, Vol. 66, No. 1 (1970), pp. 91-113.

${ }^{67}$ Abdurrahman, "Fenomena Kiai dalam Dinamika Politik: Antara Gerakan Moral dan Politik”, KARS A: Jurnal Sosial dan Budaya Keislaman, Vol. XV (2009), p. 27.

${ }^{68}$ M. Imam Zamroni, “Agama Etnis dan Politik dalam Panggung Kekuasaan: Sebuah Dinamika Politik Tauke dan Kiai di Madura", Jurnal eI-Harakah, Vol. 10, No. 1 (January-April 2008), p. 26.

${ }^{69}$ This theory adapted from a form of antagonistic relation between the West (al-ana $)$ and the East (al-äkhar) in the work of $\mathrm{H}$ \{asan $\mathrm{H}$ \{anafi, Muqaddimah fi Tlm al-Istighräb (Kairo: al-Dār al-Fanniyah li al-Nashr wa al-Tawzī‘, 1991). In his review, H anafì considers the incarnate West as the ego that is the subject and he regards the East as 
other. Dialectical connection happens between 'ulamà' (ego) who possess superiority and santri (the other) as the inferior side. 'Ulamä' are decent figures to produce every meaning of life, religion, politics, and culture. Santri, on the other side, are considered an inferior object and they will always receive the meaning produced by 'ulamā'. It seems like 'ulamä's "oppression" upon their santri, in which "ulamä's ego is capable of producing truth according to its size. This effort "locks up" (not to say "muzzle") the freedom of santri to forge proper and egalitarian relationships, which is not based on influence and dominance.

Related to the role of the BASSRA, the AUMA, and the FKM in Pamekasan, the contribution of the 'ulam $\bar{a}$ ' and lora in producing social and religious fatwas has been always ordained to patron-client pattern. In its development, the dependence of santri upon 'ulamā's religious fatwas can be exploited on the relation of non-religious reliance. Cultural, social, political, and other dimensions of life, therefore, subject to justification from the 'ulamä'. Finally, the 'ulama' has opportunity to master and provide their students protection and other benefits. The implication is that students can grant all loyalty, service, and even political support to the 'ulama'.

The 'ulamä' incorporated in the BASSRA, the AUMA, the FKM gained a place in the hearts of the Muslim community. Their mastery of santri bases in Pamekasan indicates that the 'ulama $\bar{a}$ 's figures and charisma, coupled with their families, will always have place in the hearts of the people. It has been obvious, among other examples, when they responded to the chaotic defamation of Islam committed by the former Governor of Jakarta, Basuki Tjahaja Purnama on his statement about the $51^{\text {st }}$ verse of the sūra al-Mā'ida. Religious fatwas have subsequently flew abundantly against Ahok and his statement. With no any process of tabayyun to Ahok, the Muslim community was herded by the 'ulama' to become a monolithic people; that the unity of the Islamic culture of Pamekasan society is considered to suppress non-Muslims as affirmed by the Chairman of the AUMA:

"We do come to the Third Commission of the Regional Legislative not merely for political interest. We are, even, neutral. We come from various clusters of 'ulama' such as BASRA, AUTADA, and FKM. To us, according to the decision of the Constitutional Court No. 73 of 2011, a legal process of a Regional

the other being the object. The West has always been considered powerful and everywhere always oppressive, because power has produced truth according to its size. 
Head does not need to wait for presidential permission and does not have to wait after regional election if it is related to the determination of regional election". ${ }^{70}$

To these religious organizations, the idea of global pluralism and democracy is considered incompatible with the essence of Islam. In addition to such attitude, the proof of plurality of understanding and diversity recognized by the Indonesian state must be blindly rejected. The implementation of sharia through Gerbang Salam shows that the ideology of Islamism is deeply rooted in the understanding of the Muslim community, as the majority group, in Pamekasan and it must be enacted as a regional law. ${ }^{71}$ The ideology of Gerbang Salam has been even expected by the Madurese 'ulamä' to be implemented within the national scale. As stated in their visions, goals, and tasks, the AUMA and the FKM have strong passion to stem any deceptive ideology. They will always find justification for their deeds as they believe what they fight for is a part of al-amr bi al-ma'rüf wa al-naby 'an al-munkar.

The tabligh akbar held by these organizations and attended by many other Muslim organizations in Pamekasan has been an ample exemplar of their struggles to cultivate Islamism in the area. It is identified that many kiai of NU who have associated themselves in the BASSRA, the AUMA, and the FKM, involved in such action. It means that the issue of Islamism propagated by the kiai over their santri aims to build a totalitarian order, which can be termed as nizäm Islami. When we carefully examine the Statutes of the AUMA and the FKM we will not find such words as Pancasila and democracy; two important keywords to understand the state-nation order of Indonesia. It can be predicted, therefore, that Islamic solution (al-hall al-Islämi) in Pamekasan-which has been obviously illustrated through the idea of Gerbang Salam and demonstrated in religious attitudes of the aforementioned Muslim organizations - is an attempt to reject power sharing with non-Islamic groups and people.

These organizations have never, indeed, proclaimed themselves as Muslim organizations and qualified as democratic institutions, which represent civil Islam, but they are totalitarian Islamic groups in terms of their attitudes. Bassam Tibi has, in fact, categorized NU as an

\footnotetext{
${ }^{70}$ KH. Ali Karrar Shinhaji, Interview, Pamekasan, 22 June 2017.

${ }^{71}$ See AD-ART (the statue) of the FKM page 10.
} 
Islamic organization, ${ }^{72}$ but it is apparently different from the condition of a number of kiais in Pamekasan. To the best of our knowledge, the kiais allied in the BASSRA, the AUMA, along with lora associated in the FKM can be categorized as the conservative groups of NU. Imadul Haq Fadholi son of KH. Fudholi Moh. Ruham (the Secretary of the FKM) has stated:

"National NU leaders, including KH. A. Mustofa Bisri, Prof. Dr. KH. Said Aqil Siradj, Habib Lutfi bin Yahya, and others, are considered moderate and tolerant. This is so very unlikely of our NU fellows in Pamekasan. They prefer the style of KH. Idrus Romli of Jember, KH. Najih Maimoen of Rembang, and KH. Lutfi Bashori of Malang more. These three kiais are highly favored by the senior 'ulamä' and NU's youngsters here". ${ }^{73}$

It needs to be undeniably admitted that the members of $\mathrm{NU}$ in Pamekasan are different from that of NU's members in other regions. A number of sources have even noted that some prominent leaders of NU in Pamekasan have not always obeyed the policies issued by PBNU (the Central Board of NU) in Jakarta. The members of NU in Pamekasan consider the policies issued by the Central Board as being too moderate and humble. In other words, these "cultural members" of NU reject such "moderatism" shown by the Central Board. Furthermore, these people have obviously expressed their animosity against some NU's national figures, as previously mentioned. This is so because of their thought's dissimilarity in responding to several issues faced by, particularly, the members of NU allied in the BASSRA, the AUMA, and the FKM.

Interestingly, there have been a few numbers of kiai who, in fact, "silently" rejected the action shown in the tabligh akbar and they did not involve themselves in the event. This is to argue that despite the existence of the cultural members of NU there has been a group of the "structural members" who tranquilly obey any policies issued by the Central Board of NU in Jakarta. KH. Taufik Siraj (the chairperson of PCNU in Pamekasan), for an instance, stresses that NU's members in Pamekasan, which associated in several NU's autonomous organizations such as IPNU, IPPNU, Fatayat, GP Ansor, Muslimat, PERGUNU, and PMII, fully respect and obey the policies issued by

\footnotetext{
72 See Tibi, Islamism, p. 152.

73 Imadul Haq Fadholi, Interview, Pamekasan, 27 March 2017.
} 
the leaders of $\mathrm{NU}$ in both national and provincial level. He expresses his apprehension due to the existence of individuals and/or groups who are acting on behalf of NU but they counterproductively behave against NU's central and local policies. He stresses that: "There has been no any activity within NU which is out of coordination due to its organizational complete structure ranging from the small branches to the Central Board". 74

The moderate people of NU in Pamekasan are, however, less dominant compare to the conservative one. This is so because the conservative doctrines and thoughts are more acceptable to kiai and santri. It seems that the conservative NU in Pamekasan is more adaptable to the model of puritanical thoughts promulgated by kiai of SI. It also means that the latest mentioned group put strong attention to the ideology of Islamism. The Islamist ideology puts emphasis on the very essence of Islam and rejects the idea of global pluralism and democratic peace. The people of this group maintain their worldly vision as follow:

\begin{tabular}{|c|c|c|}
\hline Issues & Trends of Thought & The Potential Islam in Pamekasan \\
\hline Law & 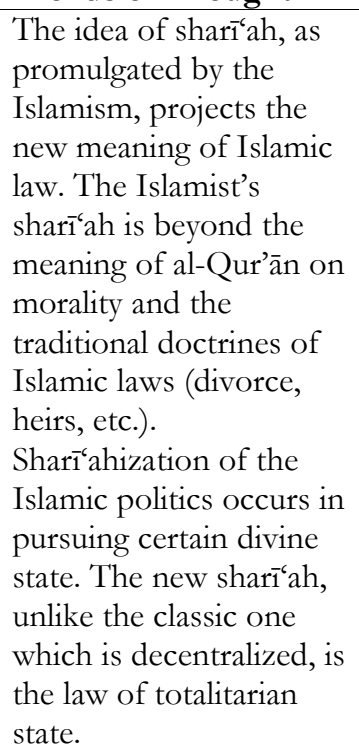 & $\begin{array}{l}\text { It has been implemented in verdict } \\
\text { of Gerbang Salam supported by } \\
\text { Islamism movement which has } \\
\text { successfully gained countless } \\
\text { members. }\end{array}$ \\
\hline Politics & $\begin{array}{l}\text { The idea of din wa dawlah } \\
\text { is a call to interpret Islam }\end{array}$ & $\begin{array}{l}\text { The ideology of Islamism potentially } \\
\text { justifies the concept of Islamic state. }\end{array}$ \\
\hline
\end{tabular}

${ }^{74}$ KH. Taufik Hasyim, Interview, Pamekasan, 16 February 2017. 


\begin{tabular}{|c|c|c|}
\hline Issues & Trends of Thought & The Potential Islam in Pamekasan \\
\hline & $\begin{array}{l}\text { as the religion of politics, } \\
\text { which govern state's } \\
\text { order based on divine } \\
\text { revelation. }\end{array}$ & $\begin{array}{l}\text { As the result of unimplemented } \\
\text { basic concepts of Pancasila in daily } \\
\text { life, the seeds of conservatism } \\
\text { become a "front gate" to the } \\
\text { acceptance of the idea of an Islamic } \\
\text { state. }\end{array}$ \\
\hline Culture & $\begin{array}{l}\text { An assumption that } \\
\text { Muslims are a monolithic } \\
\text { umma (community) who } \\
\text { share a common culture. } \\
\text { This culture becomes the } \\
\text { foundation to the } \\
\text { ideology of } \\
\text { internationalism Islam. }\end{array}$ & $\begin{array}{l}\text { Islamization of culture has } \\
\text { successfully driven the Muslim } \\
\text { society to the model of a monolithic } \\
\text { umma. This is not, however, an } \\
\text { absolute matter as for it is still } \\
\text { assured by the acceptance of } \\
\text { acculturation between the local } \\
\text { culture and Islam. }\end{array}$ \\
\hline Military & $\begin{array}{l}\text { Reinterpretation of jïhäd } \\
\text { which legitimates brutal } \\
\text { and unregulated wars. } \\
\text { The violent shown in } \\
\text { such ideology is not } \\
\text { merely a terror but a new } \\
\text { type of unusual war. }\end{array}$ & $\begin{array}{l}\text { The Islamist group has not, in fact, } \\
\text { infiltrated the military although a few } \\
\text { numbers of departments have been } \\
\text { contaminated by the ideology of } \\
\text { Islamism. The same was true when } \\
\text { some regional officials involved } \\
\text { themselves in designing Gerbang } \\
\text { Salam. }\end{array}$ \\
\hline
\end{tabular}

Typologically, their socio-political attitudes are classified in puritanical Muslim category. In many ways, the orientation of such group tends to be very puritanical and intolerant as they consider pluralism as authentically anti-Islam. The puritan Muslims believe that human was created to solely obey God. Khaled Abou El Fadl maintains that this sort of Muslims believe that every single thought they produce represents the divine message of God rooted in the sacred scripture, i.e. the Qur'an, and the original tradition of the Prophet (al-Sunna). While the puritan Muslims, on one hand, accuse their opponent groups of being a group of Muslims who want to change, undermine, and weaken Islam, the non-puritan Muslims also accuse them of being misapplying and abusing Islam to denigrate this religion. ${ }^{75}$ Among the current issues in accordance with the struggle for

${ }^{75}$ Khaled Abou El Fadl, Selamatkean Islam dari Muslim Puritan, trans. Helmi Mustofa (Jakarta: PT. Serambi Ilmu Semesta, 2006), p. 16. 
truth claims consist of human rights, democracy, jihäd, law, terrorism, and the role of women. ${ }^{76}$

Abou El Fadl further adds that in interpreting, understanding, formulating, sorting, and making decisions regarding religious verses, the puritan Muslims seem to portray divine authority. This authority is aimed solely at arbitrarily justifying their absolute-despotic and uncompromising actions when they read and interpret the religious texts (nass). By claiming that the most relevant and true understanding merely "the will of the Author", ${ }^{77}$ then the reader easily replaces the Author and regards self, groups, and institutions as the sole proprietor of the absolute source authority of truth. There will be a process of change within instant and striking ways, namely the unification of "readers" and "author" where the readers of religious texts are no longer concerned with the limitations inherent in the self and its institutions become unlimited "author". ${ }^{78}$

The production of 'ulama's religious thought in Pamekasan will pattern an authoritarian religious practice. 'Ulamä' will aggressively authorize thinking derived from religious texts understood exclusively. According to Abou El Fadl, through their religious organization, the religious elites "lock in" the will of God or the will of the texts in a certain designation, and then presenting them as definite and absolute. This authoritarian product of thought will then result in authoritarianism..$^{79}$ This sort of ideology is an act, which wishes to go beyond the mandated authority to corrupt or take over the power of the Mandate, i.e. God.

\footnotetext{
${ }^{76}$ Ibid., pp. 139-300.

77 For El Fadl, to approach the Divine God, we must go through some evidence. Among the evidence are textual sources and cultural practices. In addition, God's desire must also be observed as a moral and ethical inquiry. Khaled Abou El Fadl, Conference of the Books: The Search for Beauty in Islam (Lanham, Md.: University Press of America/Rowman and Littlefield, 2001), p. 115.

${ }^{78}$ M. Amin Abdullah, "Introduction" in Khaled M. Abou El-Fadl, Atas Nama Tuban: Dari Fikih Otoriter ke Fikih Otoritatif, trans. Cecep Lukman Yasin (Jakarta: PT. Serambi Ilmu Semesta, 2004), pp. x-xi.

${ }^{79}$ For El Fadl, authoritarianism refers to a hermeneutical methodology that robs and subjects the mechanism of searching the meaning of the text into subjective and selective readings. The subjectivity and selectivity in authoritarian hermeneutics involve the equalization of author and reader intention and positioning text autonomy in the secondary region. That is, there are indications that textual intentions are not important anymore. El Fadl, Atas Nama Tuban, p. 16.
} 
This is also the act of those who use symbolism of a particular interpretation of laws to support their argument. Therefore, objective (authoritative) texts will have dialectics with subjective axis of the reader or interpreter. It must be acknowledged that any process of interpretation or understanding-whatever the form-cannot be separated from the element of subjectivism, both individual and collective, involving an institution with a claim to be the right holder of the interpreter of God's will. If so, then the product of subjective interpretation, as Abou El Fadl further argues, can actually fall into the trap of authoritarianism. ${ }^{80}$

Within the example of Ahok's religious blasphemy, 'ulamä' have issued related fatwas to urge the government to immediately process his case and imprison him. As good and honest as any leader, if he is non-Muslim, then he will not get his rights perfectly in Indonesia, including the right to be a leader. Thus, the call to review the concept of abl al-dhimmah in the modern context will also appear. Muhammad Nazeer Kaka Khel suggested that non-Muslim rights in an Islamic state stand on the principle of tolerance, justice and equality, suggesting that there is a new ijtihad to place the rights of non-Muslims in it. ${ }^{81}$

A Tunisian national thinker, Rashid al-Ghannūshi (b. 1941), states that currently abl al-dhimmah or non-Muslims should get all rights such as freedom of faith including the Muslims who want to convert; holding public office, equal treatment between Muslims and nonMuslims in tax rights and obligations. He emphasized that the point of departure of his argument was based on the principle of justice as the main pillar of Islamic law. ${ }^{82}$ In line with him, Abdullah Ahmed anNa'im (b. 1946), a Sudanese thinker, holds that the classical sharia products leave a highly discriminatory space, especially with regard to non-Muslim rights. Thus, referring to the problematic relationship between religions, an-Na'im reveals that the classical sharia, when

\footnotetext{
${ }^{80}$ Ibid., p. 207.

${ }^{81}$ Muhammad Nazeer Kaka Khel, "The Rights of non-Muslim in Islamic State”, dalam http://www.qurtuba.edu.pk /thedialogue/The\%20Dialogue/1_2/5_Dr.\%20 M.\%20 Nazir.pdf. Cited from Mary Silvita, "Presiden Non-Muslim dalam Komunitas Masyarakat Muslim”, Islamica: Jurnal Studi Keislaman, Vol. 7 No. 1, September (2012), p. 52.

82 Abdullah Saeed, "Rethinking Citizenship Rights of non-Muslims in an Islamic State: Rāshid al-Ghannūshi's Contribution to the Evolving Debate", Islam and ChristianMuslim Relations, Vol. 10, No. 3 (1999), pp. 307-323.
} 
associated with problem of discrimination against the rights of nonMuslim minorities, is no longer applicable. ${ }^{83}$ For that reason, there should be need for ijtihäd changes in the rights and obligations of nonMuslim citizens in modern Islamic countries, including in Indonesia. This means that in the context of modernity, non-Muslim can no longer be treated as abl al-dhimmah. Hence, the ijtibäd about not allowing non-Muslims to occupy strategic positions in the governmental sphere and the position of non-Muslims as abl aldhimmah during kbiläfah era is subject to review. ${ }^{84}$

If the conservatism of thought and movement of Islamism in Pamekasan is allowed to grow rapidly, the movement would easily evolve into a radical fundamentalism movement. Islamic radicalism is associated with the teachings of a number of propaganda suc as al-amr bi al-ma'rüf wa al-naby 'an al-munkar, jihād, and the unbelievers, which are interpreted exclusively and rigidly within radical attitude. It may be that the Islamists who interpret the verses of the Qur'ān exclusively with a textual-literalist approach and has led to radicalism, while being interpreted with a substantive-contextual approach will bring about moderate or non-radical attitudes.

Masdar Hilmy identifies radical Islamic groups as individuals and groups or organizations. He asserted that as individuals, Islamic groups can be found everywhere, especially outside of formal organizations registered by the Ministry of Justice and Human Rights. There is usually no organizational relationship that binds the radicals. However ideological similarities can be a focal point where most of the Islamic groups are trapped as a whole. As far as the research on radical Islamism is concerned, there is no clear figure as to how many individuals in Indonesia incorporate radical Islamic ideology. From Edward Said's theory, Hilmy argues that this is because ideology of radical Islamism "can move from one mind to another." Yet, ideological similarity does not mean that they are bound in the same

\footnotetext{
83 Abdullah Ahmed an-Naim, "Syariah dan Isu-isu HAM", in Charles Kurzman (ed.), Wacana Islam Liberal: Pemikiran Islam Kontemporer tentang Isu-isu Global (Jakarta: Paramadina, 2001).

84 To understand more about the problems of non-Muslim presidents in Muslimmajority countries can be read, among other, in the article of Silvita, "Presiden NonMuslim", pp. 44-60.
} 
organization. In other words, only ideological similarities connect them in their vision of Islamism. ${ }^{85}$

In this case, ideology of Islamism which has been discoursed by the 'ulama' in Pamekasan can certainly improve religious sentiments and escalate into a sectarian community. Sectarianism can emerge in a variety of simple beginnings, that is simply a gift of blessing from religious and political elites to political behavior and policy; a sort of justification of violence. Azyumardi Azra maintains that such sectarianism contains "intra and interreligious hatred or entropy, flow, denomination of religion, and social class, between ethnic and political groups". 86

With the socio-historical burden of multi-layered sectarianismfrom the breakup of partnership between 'Alī b. Abī Tāalib and $\mathrm{Mu}^{6}$ äwiyah to Crusades ${ }^{87}$ - embers of hatred on the basis of different religions, understandings, streams, and denominations which then mingle with social, cultural, and political sectarianism continue today.

Considering the reality of diversity and inter and intra ethnic groups in Pamekasan, vigilance and seriousness of all stakeholders needs to be increased in order to prevent growth of sectarianism. Religious, social and political leaders should be aware of and make efforts through their respective institutions to prevent sectarianism from flourishing and at the same time strengthen the harmony and mutual respect of the differences between different intra and interreligious groups, ethnic groups and political factions.

Above all, the government needs to show more firm attitude in preventing the proliferation of sectarianism in society. In addition, efforts to create harmony and mutual respect among community groups need to be more empowered and intensively propagated

85 Masdar Hilmy, "The Configuration of Radical Islamism in Indonesia: Some Contemporary Assessments and Trajectories", al-Tahrir: Jurnal Pemikiran Islam, Vol. 14, No. 1 (May 2014), pp. 4-5.

86 Azyumardi Azra, Transformasi Politik Islam: Radikalisme, Khilafatisme, dan Demokrasi (Jakarta: Pranadamedia Group, 2016), p. 274.

${ }^{87}$ In addition, the $18^{\text {th }}$ century AD is often seen as the dark time of Islamic history (the Dark Age). This picture stems from the split that occurred in the imperial government and the general decline of the Islamic world. This perception is influenced by knowledge of some experiences of Islam, because this century is a period of loss of Islamic rules and they were under the rule of Western colonial. See, among other, John Obert Voll, Politik Islam: Kelangsungan dan Perubahan di Dunia Modern, trans. Ajat Sudrajat (Jakarta: Penerbit Ilahi Press, 2001), p. 59. 
through education and socialization of the four pillars of the nationstate of Indonesia, namely the 1945 Constitution, Pancasila, NKRI, and Bhinneka Tunggal Ika.

\section{Conclusion}

Islamism in Pamekasan is a result of "politicization" of religion. When the religion, which is being politicized, is the sole indication of a cultural mixture, we should then be able to make a sort of "chamber" for it on behalf of diversity. Nonetheless, Islamism in Pamekasan-as a particular variant of Islam which is closely related to the global phenomenon of religious fundamentalism - threatens and is uniquely focused on the national order (outside Madura), namely nationalization of Islam. The Islamist groups in Pamekasan attempt to mobilize their members in the name of religion in order to establish not only an Islamic state but also to revive Indonesia. Thus, Islamism in Pamekasan is a vision above a national order based on politicized religion. Islamism in Pamekasan is not an adequate alternative to the civil society for this type of Islam is unable to sincerely accept the very essential values which-among the civil society—should be possessed by all. The Islamist kiai seem to conceivably reject the power sharing even with their NU moderate brothers and, therefore, the latest mentioned group would be always alien to them.

Given the fact that Islamism is a new type of authoritarianism and totalitarianism, the Muslim community in general should not let the Islamists freely propagate their thoughts and easily speak on behalf of Islam and it civilizations. The non-Islamist Muslims should, therefore, provide the society obvious and adequate solutions to the happening and forthcoming crises and at the same time avoiding any thought and action which would possibly exacerbate the crises. The moderate Muslim organizations and the government should continuously work hand-in-hand to educate the Islamist santri but the Islamist kiai altogether in order to sincerely open their minds and accept differences as a part of Sunnat Allah. We do, therefore, hope that such education will open the roadmap for the reformation of religion and cultural changes which will subsequently lead to the birth of true democracy. It needs to be seen that Islamism in Pamekasan is a response to social crises occur in Madura. The ideology will be, unfortunately, unable to solve the crises. This is so because Indonesia has clearly proclaimed itself as a state which respectfully embraces diversities and differences. 
In defending the universal values of cultural enlightenment against unfavorable model of Islamism, such as in Pamekasan, we need to open-mindedly look at humanism, which has always been part of the Islamic heritage. []

\section{References}

\section{Books and Articles}

Abdullah, M. Amin. "Kata Pengantar" Khaled M. Abou El-Fadl, Atas Nama Tuhan: Dari Fikih Otoriter ke Fikih Otoritatif, trans. Cecep Lukman Yasin. Jakarta: PT. Serambi Ilmu Semesta, 2004.

Abdurrahman. "Fenomena Kiai dalam Dinamika Politik: Antara Gerakan Moral dan Politik." KARSA: Jurnal Sosial dan Budaya KeIslaman, Vol. XV, 2009.

Adrisijanti, Inajati et al. Ensiklopedi Pamekasan: Alam, Masyarakat dan Budaya. Pamekasan: Pemkab Pamekasan and Fakultas Ilmu Budaya Universitas Gadjah Mada, 2010.

an-Naim, Abdullah Ahmed. "Syariah dan Isu-isu HAM." in Charles Kurzman (ed.). Wacana Islam Liberal: Pemikiran Islam Kontemporer tentang Isu-isu Global. Jakarta: Paramadina, 2001.

Arendt, Hannah. "The Totalitarianism of Jihadist Islamism", Totalitarian Movement and Political Religion, Vol. 8, No. 1, March 2007.

--------- The Origins of Totalitarianism. New York: Harcourt Inc., 1951.

Azra, Azyumardi. Transformasi Politik Islam: Radikalisme, Kbilafatisme, dan Demokrasi. Jakarta: Pranadamedia Group, 2016.

Chalik, Abdul. "Elite Lokal Berbasis Pesantren dalam Kontestasi Pemilihan Kepala Daerah di Jawa Timur." KARS A: Jurnal Sosial dan Budaya KeIslaman, Vol. 23 No. 2. December 2015.

de Jonge, Huub. Madura dalam Empat Zaman: Pedagang, Perkembangan, Ekonomi, dan Islam. Jakarta: Gramedia, 1989.

Dhofier, Zamakhsari. Tradisi Pesantren: Studi tentang Pandangan Hidup Kyai. Jakarta: LP3ES, 1982.

El Fadl, Khaled Abou. Atas Nama Tuhan: Dari Fikih Otoriter ke Fikih Otoritatif, trans. Cecep Lukman Yasin. Jakarta: PT. Serambi Ilmu Semesta, 2004. 
. Selamatkan Islam dari Muslim Puritan, trans. Helmi Mustofa. Jakarta: PT. Serambi Ilmu Semesta, 2006.

Faruq, Umar. "BASSRA dan Rencana Industrialisasi di Madura: Kajian Historis Peran Politik Kiai 1991-1997.” Unpublished Bachelor Thesis, UIN Sunan Kalijaga, Yogyakarta, 2009.

Gani, M. Abdul. Cita Dasar dan Pola Perjuangan Syarikat Islam. Jakarta: Bulan Bintang, 1984.

Ḥanafì, Hasan. Muqaddimah fì Tlm al-Istighräb. Kairo: al-Dār al-Fanniyah li al-Nashr wa al-Tawzī‘ 1991.

Hamdi, Ahmad Zainul. "Pergeseran Islam Madura: Perjumpaan Islam Tradisional dan Islamisme di Bangkalan, Madura, PascaReformasi." Unpublished PhD Dissertation, UIN Sunan Ampel Surabaya, 2015.

Hariyanto, Erie. "Gerbang Salam: Telaah atas Pelaksanaanya di Kabupaten Pamekasan." KARSA: Journal of Social and Islamic Culture, Vol. 17, No. 1, April 2009.

Hilmy, Masdar. "The Configuration of Radical Islamism in Indonesia: Some Contemporary Assessments and Trajectories." al-Tabrir: Jurnal Pemikiran Islam, Vol. 14, No. 1, May 2014.

Khel, Muhammad Nazeer Kaka. "The Rights of non-Muslim in Islamic State", in http://www.qurtuba.edu.pk /thedialogue/The\%20Dialogue/1_2/5_Dr.\%20 M.\%20 Nazir.pdf.

Kuntowijoyo. "Agama Islam dan Politik: Gerakan-gerakan Sarekat Islam Lokal di Madura 1913-1920." Huub de Jonge (ed.). Agama, Kebudayaan, dan Ekonomi. Jakarta: Rajawali Press, 1989.

Kutwa, et.al. Pamekasan dalam Sejarah. Pamekasan: Pemerintah Daerah Pamekasan, 2004.

Madjid, Nurcholish. Bilik-bilik Pesantren: Sebuah Potret Perjalanan. Jakarta: Paramadina, 1997.

Mansurnoor, Iik Arifin. Islam in an Indonesian World: Ulama of Madura. Yogyakarta: Gadjah Mada University Press, 1990.

Mozaffari, Mehdi. "What is Islamism? History and Definition of a Concept." Totalitarian Movements and Political Religions, Vol. 8, No. 1, March 2007. 
Mutmainnah. Jembatan Suramadu: Respon Ulama terhadap Industrialisasi. Yogyakarta: LKPSM, 1998.

Pribadi, Yanwar. "Kiai in Madura: Their Roles in Local Politics in Indonesia." American Journal of Islamic Social Sciences, Vol. 29, No. 3, 2012.

---------. "Relasi Kiai, Masyarakat, dan Negara: Konfigurasi Politik Pemilu pada Masa Orde Baru di Madura." Maarif: Arus Pemikiran Islam dan Sosial, Vol. 8, No. 2, 2013.

-. "Religious Networks in Madura: Pesantren, Nahdlatul Ulama and Kiai as the Core of Santri Culture." Al-Jamiah: Journal of Islamic Studies, Vol. 51, No. 2, 2013.

---------. 'Renegotiating Islam: The Kiai and People's Resistance against the Government in the 1993 Nipah Dam Incident in Sampang, Madura." The 13th Annual International Conference on Islamic Studies (AICIS), 2013.

---------. "The Suramadu Bridge Affair: Un-bridging the State and the Kiai in New Order Madura." Studia Islamika, Vol. 22, No. 2, 2015.

---------. "Village Politics in Madura, Indonesia: Influential Community Figures in Search of Influence." The 14th Annual International Conference on Islamic Studies (AICIS), Balikpapan 2014.

Quṭb, Muḥammad. Jāhillīyat al-Qarn al-'Ishrīn. Cairo: Dār al-Shurūq, 1964.

Roy, Olivier. Globalised Islam: The Search for a New Ummah. London: Hurst and Company, 2002.

Saeed, Abdullah. "Rethinking Citizenship Rights of non-Muslims in an Islamic State: Rāshid al-Ghannūshi's Contribution to the Evolving Debate." Islam and Christian-Muslim Relations, Vol. 10, No. 3, 1999.

Sattar, Abdullah. "Badan Silaturrahmi Ulama Madura (BASSRA): Dakwah Multi Fungsi." Jurnal Komunikasi Islam, Vol. 02, No. 01, June 2012.

Scott, James C. "Patron-client Politics and Political Change in Southeast Asia." American Political Science Review, Vol. 66, No. 1, 1970. 
Sholichin, Mohammad Muchlis. "Perilaku Politik Kiai di Pamekasan." KARS A: Jurnal Sosial dan Budaya KeIslaman, Vol. XV, 2009.

Silvita, Mary. "Presiden Non-Muslim dalam Komunitas Masyarakat Muslim." Islamica: Jurnal Studi Keislaman, Vol. 7 No. 1, September 2012.

Tibi, Bassam. Islamism and Islam. trans. Alfathri Adlin. Bandung: Mizan, 2016.

Touwen-Bouwsma, Elly. "The Ulama of Madura: Rise and Expansion of a Religious Administration." Mart Bax et.al (eds). Faith and Polity on Religion and Politics. Amsterdam: VU University Press, 1992.

van Bruinessen, Martin. "Tarekat and Tarekat Teachers in Madurese Society." in Kees van Dijk, Huub de Jonge and Elly TouwenBouwsma (eds). Across Madura Strait: the Dynamics of an Insular Society. Leiden: KITLV Press, 1995.

Voll, John Obert. Politik Islam: Kelangsungan dan Perubahan di Dunia Modern. trans. Ajat Sudrajat. Jakarta: Penerbit Ilahi Press, 2001.

Wiyata, A. Latief. Carok: Konflik Kekerasan dan Harga Diri Orang Madura. Yogyakarta: LKiS, 2006.

Zainalfattah. Sedjarah tjaranja pemerintahan di daerah-daerah di kepulauan Madura dengan bubungannja. n.p.: Paragon Press, 1952

Zamroni, M. Imam. "Agama Etnis dan Politik dalam Panggung Kekuasaan: Sebuah Dinamika Politik Tauke dan Kiai di Madura." Jurnal eI-Harakah, Vol. 10, No. 1, January-April 2008.

\section{Interviews}

Interview with KH. Taufik Hasyim, Pamekasan, 16 February 2017.

Interview with Imadul Haq Fadholi, Pamekasan, 21 February 2017.

Interview with Imadul Haq Fadholi, Pamekasan, 22 February 2017.

Interview with KH. Lailurrahman, Pamekasan, 22 February 2017.

Interview with Daeng Ali Taufik, Pamekasan, 23 February 2017.

Interview with Imadul Haq Fadholi, Pamekasan, 27 March 2017.

Interview with KH. Ali Karrar Shinhaji, Pamekasan, 22 June 2017. 


\section{Internet Sources}

"Antisipasi Masuknya Paham Wahabi dan Syiah Auma Dideklarasikan" http://maduranewsmedia.com/terkini/

"BASSRA Bentengi Aswaja Madura dari Wahabi Syiah dan Aliran Sesat", http://www.nugarislurus.com/2016/01/

"Sunni-Syiah: Politik Penyesatan vs Politik Kewargaan" http://liputanislam.com/opini/

"Syarat Pembentukan Provinsi Baru Diuji", http://www.mahkamahkonstitusi.go.id/index/

“Tunjuk Pengacara Aliansi Ulama Madura akan Laporkan Ahok ke Polda Jatim" http:// portalmadura.com/

"Ulama Madura Deklarasi Tolak Paham Sesat", http://www.republika.co.id/berita/nasional /daerah/15/11/01/

"Ulama Madura LGBT Ancam Keberlangsungan Peradaban Manusia" http://news.okezone.com/read/2016/02/19 / /519/1316657/ and http://m.metrotvnews.com / read/2016/02/22/487916/

“Ulama Madura Minta Polisi Tegakkan Hukum” http://edukasi.kompas.com/read/ 2012/09/07/20183989/

"Ulama se-Madura Laporkan Ahok ke Polda" http://beritaotomatis.blogspot.co.id/2016/10/

http://www.moslemwiki.com/Pesantren_di_Kota_Pamekasan/

http://www.pamekasankab.bps.go.id/linkTabelStatis/view/id/191/ 
Abd A'la, Mukhammad Zamzami, Nur Hidayat Wakhid Udin, and Ahmad Fathan Aniq

194 JOURNAL OF INDONESIAN ISLAM

VOLUME 12, NUMBER O2, DECEMBER 2018 